\title{
AFRICAN FOLKLORE: A CATALYST IN CONTEMPORARY AFRICAN FICTIONS
}

\author{
Joshua USMAN ${ }^{1}$ \\ Marius CROUS ${ }^{2}$ \\ Department of Language and Literature \\ Nelson Mandela University, Port Elizabeth, South Africa \\ 1usmanautaj5@gmail.com* \\ 2marius.crous@mandela.ac.za
}

Manuscript received 24 August 2018

Manuscript accepted 9 November 2018

\begin{abstract}
African folklore which are said to be active traditions have had immense influence on the growth and development of African literature. This claim is aptly demonstrated in the works of successful early African writers as in the case of Amos Tutuola and Daniel O. Fagunwa of Nigeria, Violet Dube in Zulu, S.E.K. Mghayi in Xhosa and a host of them. These literary artists draw their inspiration from the oral tradition by translating their structures and images to literary mode. It is on this platform that the article seeks to examine this claim in the light of the state of African literature today. This paper adopts Cyprian Ekwensi's African Night's Entertainment as a case study to demonstrate how present African writers build on that trend to success. Ekwensi is considered one of the pioneers of African literature and writing fiction in English in West Africa. Ekwensi's works observed oral conventions in terms of themes, style and other motifs; but literary in its form. The book adopts tales from African cultural background. This article establishes that contemporary African writers owe much to African oral tradition in their various domains of literary inspirations.
\end{abstract}

Keywords: Folklore, catalyst, pacesetter, African literature

\section{Introduction}

Literary writers and scholars such as Ousmane Sambene, Isidore Okpewho, Wole Soyinka, Chinua Achebe and Amos Tutuola attest to the fact that African modern literature in line with Nigerian literature grows out of a tradition of storytelling and historical remembrance that has existed in Nigeria for ages. Folktale is the most well-known form of orality in African literature apart from oral performance, legend, myth and proverbs (Finnegan, 2017). Myths in all directions consist of creation stories that have to do with the universe. Myth also explains the 
activities of the deities at the beginning of creation, the aim of all creatures and nature of their interrelationships. Legend is the next in thought, which describe or explains the events that took place after the age of the gods. It explains the heroic human accomplishments such as constituting empires or dynasties and preventing calamity. The African legendary is synonymous to epic in their attention on heroism. The legendary act is demonstrated in the context of daily life, but epics that are more elaborate are always performed on special occasions (Westley, 1991).

The folktale is the commonest oral prose form, it is always told at night as a form of entertainment. They are mostly fictional stories told about animals, human beings and some gods. Sometimes a story features these groups separately or fuse them together. Folktales are sometimes meant for moral instructions, socio-cultural commentaries or used to emphasise group values and teach against anti-social behaviour. In Africa or Nigeria to be precise, popular folktales like the flying carpet or the trick star demonstrates crafty animals and their craftiness to defend or protect themselves to avoid wild and bigger animals. For instance, Àjàpá, a tortoise in Yoruba folklore of Nigeria; and Sungura, a hare found in central and East African folklore. Most African cultures employ a rich repertoire of jokes or witticism, which include riddles and proverbs. It is common in African society to accompany eloquent speech with a good knowledge of proverbs. It is believed that proverbs express the wisdom of ages and are also used for classroom argument or discussion. Riddles are closely related to proverbs. This requires the listeners to comprehend or deduce the intended meaning. The folktale, known to be a form of traditional fiction is usually told for night time entertainment. Folktales feature human beings and animals, either separately or together. They are often employed for social commentary and instruction and also serve as a potent means of affirming group values and discouraging antisocial behaviour (Devantine, 2009)

From inception, Africa is known to be an oral society well rooted in diverse languages and traditional cultures. The multi-ethnic nature of Africa makes it difficult for literatures in African languages to get the desired attention. In addition to this, most literary scholars from Africa's cultural background do not understand African languages other than theirs. Ekwealor (2009) states that the introduction of literature in European languages later became a central point of literary attraction where literary artists share their ideas for global effect. Nevertheless, some of the best-known few literatures in African languages include those in Yoruba and Hausa in West Africa; Sotho, Xhosa, and Zulu in southern Africa; and Amharic, Somali, and Swahili in East Africa. In a later development, African literatures attained its height in 1986, when African literary writers in the likes of Wole Soyinka became the first African to win the Nobel Prize for literature. Indeed, extending the range of international literary awards has provided a powerful enticement to African writers. In spite of these major developments, the African society still remains glued to its traditional cultures. These traditional cultures or oral traditions are also used to identify African presence on various writings (Ekwealor, 2009). 


\section{Oral Tradition and Development of Literary Tradition in Nigeria}

Prior to 1500 , the present-day Nigeria was a collection of tribal groups in the form of empires, kingdoms, chiefdoms and community tribe habitations (Chapin, 1992). These settlements were based on ethnic groups. The early kingdoms in Nigeria were the Hausa empires, Benin, Yoruba and Nupe kingdoms. Neighbouring empires and kingdoms also overlapped into the Nigerian territories like the south and west of Lake Chad which constituted an extension of Kanem Borno Empire (Chapin, 1992). There were many other smaller states that probably existed alongside these wellknown settlements but history and archaeological data as well as oral tradition could not provide details of their accurate dates and antiquities.

\section{Ethnic Groups in Nigeria}

In modern-day Nigeria, there are over 350 ethnic groups that exist as an entity; with none claiming the-middle-of-the-road position. However, the three major languages as well as largest of the ethnic groups are Yoruba, Hausa and Igbo. According to Emenyonu (1978), these three groups accounted for these percentages of the entire population of the country: Hausa (28\%), Yoruba (22\%), and Igbo (20-22\%). Other ethnic groups that are well numbered within the axes of these three languages are the Ijaw people of Southern Nigerian that approximately make up for about $12 \%$ in population, followed by the Fulani and Kanuri people from the far North of about $10 \%$ each. The Ibibio (4\%), Nupe people (5\%) and the Tiv people and the Gbagyi people have $3 \%$ population each. Other minority languages of over three hundred sprinkle around the axes of these major languages.

The Hausa people dominate the Northern part of the country covering about $50 \%$ of the population in the North. Besides that, the Hausa language is the dominant lingua franca in the Northern part of Nigeria. The Yoruba preponderates the Western part of the country and virtually, covering about $98 \%$ population of the region. While the Igbo ethnic population dominates the Eastern part of the country with a population of about $70 \%$ in Eastern Nigeria. There are over 350 languages in Nigeria, the three major languages are widely spoken both as mother tongue and lingua franca in their respective regions, leaving English as the sole official language (Emenyonu, 1978).

In Nigeria, religious affiliations are well rooted in ethnicity. Colonial invasions immensely influence the regional religious majority. The coming of Christian missionaries through the west, east and south greatly influenced their Christianity. In the same vein, the invasion of the North by the Muslim Arabs influenced Islam in the far North. The North central is a blend of Christians and Muslims. The Hausa and Fulani people are predominantly Muslims. The Igbo people are dominantly Christians of Roman Catholic, Methodist and less of Protestant churches. The Yoruba people are a mix of Christians and Muslims.

The influence of oral tradition on the development literary tradition in Nigeria demonstrates that the people's rooted oral tradition has served as a bedrock or catalyst to literary development in Nigeria. Traditional epic and folktales, for example, influenced the rise of the novel and early writers of the $20^{\text {th }}$ century. 
Orality and its different contexts of application are being transformed into literary works. Early Nigerian writers like Cyprian Ekwensi's African Nights Entertainment is a reduplication of a collection of traditional folktales and other forms of oral tradition narrated in literary form. Wole Soyinka's Death and the King's Horseman is a replica of the people's inherited beliefs and culture that is given a literary pattern. Ola Rotimi's The Gods Are Not To Blame is a traditional belief that is imitated in a literary form. Other Nigerian and African writers like Amos Tutuola, D.O. Fagunwa in Yoruba, and Samuel Edward Krune Mghayi in Xhosa have their works either retold, recast or transcribe materials from the oral tradition.

Folklore has contributed greatly to the successes of most early African writers who knew the resources embedded in the oral tradition of the people. These writers use the images, material resources and the structures of the people's tradition and reinvent them using literary approach. Archibalg Campbell Jordan in Xhosa, Guybon Sinxo, Oliver Kgadime Matsepe in Sotho, Rolfes Robert Reginald Dhlomo in Zulu and Oswald Mtshali have drawn immensely from oral sources. These African writers owe so much to the oral tradition in Africa. Folklore is viewed from Africa's standpoint by Ukadike (2003), as the entire oral tradition of African people, the whole oral discourse on every subject and in every form of expression initiated by people of African descent. Goody and Watt (1963) comment on see it as orature which is a form of expression, therefore, includes song, dance, folklore, rites and ceremonies stored in human memory and transmitted verbally.

\section{Literature Review}

Ukadike (2000) and Devantine (2009) are in support that Africa is believed to be an oral society deeply rooted in various languages and traditional cultures. In conjunction with this, Haley (1976) attests that the continent has a long history of oral antecedents:

History of our ancestors and the society they lived in was usually remembered by people and kept alive by word of mouth. In most ancient societies including those of Africa, legacies, culture and traditions were passed from one generation to other by this 'Oral Tradition'. While books did get written, the best account of life and times of ordinary men and women of Africa can often be found in the oral traditions of the society. (p. 179)

The multi ethnic and cultural differences in Africa make the literature in African languages not to receive the desired scholarly attention. This is because most scholars in African culture do not know other African languages other than their own. Secondly, the introduction of literature in European languages later became a central point of literary attraction where literary artists rendered their ideas for global effect. Nevertheless, some of the best-known literatures in African languages include those in Yoruba and Hausa in West Africa; Sotho, Xhosa, and Zulu in southern Africa; and Amharic, Somali, and Swahili in East Africa. In a later development, African literatures achieved an important milestone in 1986, when 
Wole Soyinka became the first African to win the Nobel Prize for literature. Indeed, the spread of international literary awards has offered a powerful incentive to African writers. In spite of these major developments, the African society still holds traditional cultures in high esteem.

\section{Literary Writing in Nigerian Languages}

Many Nigerian languages found it quite challenging to produce standard orthography in their indigenous languages. This is due to the fact that most of the orthographies in local languages were not fully developed. Nevertheless, a few of literary writings later emerged in the form of literary novels especially in the three major languages. In the Hausa language of Nigeria, the earliest novel written was that of Muhammadu Bello titled Gandoki which was launched in 1933 by the translation Bureau in Northern Nigeria. Bello's novel blends and dilutes the typical Hausa oral tradition and literary narratives, giving it a heroic pattern using a strong trace of Islamic history. History assumes that writing in Hausa dates back to the $14^{\text {th }}$ and $15^{\text {th }}$ century. These were mostly Arabic writings among the Hausa people. Early Hausa poets include Ibn Al-Sabbagh, Muhammad al-Barnawi, Abdullahi Sikka and others.

The development of Hausa drama is greatly influenced by the people's rooted oral tradition. Hausa playwrights like Aminu Kano, Adamu dan Goggo, Dauda Kano, Muhammad Sada who have written a lot on Hausa folktales and fairy tales. These plays include; Alura chikin ruwa, (Needle in Haystack), littaffian Soyayya (Books of love), wa ya san gobe?(Who knows Tomorrow?), Ki yarda da ni (Believe in $\mathrm{Me}$ ) and host of others.

In Yoruba language, most writings are a development of Yoruba traditional tales. One the popular writers in Yoruba language is D. O. Fagunwa who produced a novel in Yoruba based on folktale titled Ogboju ode ninu igbo irumalein 1938 (The Forest of a Thousand Demons). The development of Yoruba literature has dual strands; that is, those that are highly influenced by rich Yoruba oral tradition and those influenced by western literary patterns. In the little time of indigenous language writing, Yoruba English literary writers like Wole Soyinka, Amos Tutuola, Daniel O. Fagunwa, Femi Osofisan, Ola Rotimi, Niyi Osundare and others emerged with their writings in English. Nevertheless, the literary writers weaved elements of Yoruba culture into English literary fictions. Famous among them are Wole Soyinka's early works: The Lion and the Jewel (1963), A dance of the forest (1963), African Culture: The Rhythms of Uniity (1985), Death and the King's Horse Man (1975) and Kongi's Harvest (1972).

Little of literary writing in lgbo language was done before the advent of African English literary writers. The little Igbo language literature was more of Igbo oral literature. Prose narratives in Igbo were of imaginary stories or events that emanated from Igbo oral literature. The rise of Igbo English literary writers like Chinua Achebe, Ben Okri, Buchi Emecheta, Chimamanda Ngozi Adichie and others changed the course of literary writing from Igbo language to English literary writing. But not far-fetched, these Igbo literary writers also took the pattern of the Igbo oral tradition. Chinua Achebe's early fictions like Things Fall Apart (1958), Arrow of God 
(1964), No longer at Ease (1966), Chike and the River (1966) and The Drum (1979) account for the colonial experience of the Igbo people. Chinua Achebe weaves together the Igbo oral tradition with folktales. Despite this, early prose fiction in Igbo language is said to be rooted in Igbo oral tradition. Emenyonu (1978) opines that the modern Igbo prose fiction, poetry and drama took their roots in the Igbo oral tradition. Expatiating on this, Onyekaonwu (1986) stated that "creative writers in Igbo see the body of Igbo oral tradition as a means or rich source of literary materials; open to them for exploitation for the purpose of writing their own original works". In addition, Okpehwo $(1979$, p. 1) stated that "yhe store-house of folk myth and fancy are gainfully plundered by writers for their own original literary production.

Similarly, Ekwealor (2009) stated that the Igbo traditional stories (folktales) serve as a vital instrument for the contemporary Igbo prose writers. Many modern Igbo prose writings draw a lot from the Igbo traditional stories, while in some cases elements of oral tradition are incorporated in these writings. Some Igbo oral forms like anecdotes, Igbo myths, proverbs, oral performance and folktales tremendously influenced their works. The adoption of traditional story technique is seen in D. N. Achara's Ala Bingo; in which the plot in this early Igbo novel is said to be a remodelling of an Igbo 'Iduu, a type of traditional folktale titled The famous king of the mountains.

\section{The Tradition of Storytelling on Nigerian Traditional Setting}

\section{Tales by Moonlight}

Having been brought up in a rural setting, and having lived a pastoral life, the experience was quite exciting. That life was more about survival in a less competing world. One of the exciting memories of those times were stories narrated by our parents. Some are fictional while some from their life experiences. Every day after supper, we sat around our parents all ears in anticipation of their wonderful stories. Some stories are philosophical, stories about why the tortoise has a cracked shell, how the lion became the king of the animals, why the hare has long ears, why the chameleon changes different colours, the hare (wise) and the hyena (foolish), and others.

At every point in time, parents do ask us about the moral lessons we learn from those stories. A lot of lessons ranging from one should be honest, refrain from greed, good to strangers or visitors to being hardworking, wise, and diligent. As an Army officer, my father does tell us his experience in the Army, in particular the civil war of Biafra in the 1960s. How the Igbo people decided to split and call their new state Republic of Biafra. He told us how the then government counter the idea of secession, saying that Nigeria must be one.

The war between the Nigerian government and the Biafra (Igbo) soldiers lasted three and the half years. There was mass massacre of the Igbo people as they were at a disadvantage compared to the Nigerian military who were militarily well equipped. 
He told us how the Biafra soldiers took advantage of their friendliness with monkeys to attack Nigerian soldiers. Then, the Igbo people do not eat monkeys rather they even give them food. Therefore, the monkeys became friendly with Biafra soldiers, any time the Nigerian Army approached the territory of the Biafra the monkeys would alert them. So, with these techniques they slew many of Nigerian Army. The Nigerian soldiers later discovered this tactic and began to kill the monkeys sporadically. Hunger and strife among the Igbo people led them to surrender. At the end, my father said we need animals around us because when we feed them, they in turn protect us. This story boils down to why the dog became a domestic animal.

\section{Fireside Stories}

It was a common trend that when the moon is hidden in its time of disappearance, the next available option is to sit by the fire side and tell our stories. Fireside stories are common among children and peers. We take turns in storytelling whether fictitious or folktales. Everyone will go into creativity to entertain ourselves. Most of our stories are of animal kingdom which are either read or told and retold. Little did we know that these stories make great impact in our lives. Such storytelling to a large extent boosted my literary prowess.

\section{Village Square Play and Dances}

In virtually every rural community, there is always a playground in a central place where the young and adult as well as children gathered to play, sing and dance in the night. This is done in order to reduce the loneliness or idleness of the day. These nocturnal activities are usually entertaining; therefore, the people always look forward to taking the advantage to ease their bored life. The activities comprises village drummers and young girls and boys that are good at dancing. While the aged are glued to the fireside in the huts, the youths are busy entertaining themselves in the square. Most youths use this opportunity to woo young girls into becoming their future betroths. It is usually an exciting event to behold.

\section{Playing the Hide and Seek}

The Nigerian version of the hide and seek is called "Boju-Boju" in Hausa. It is an act where someone goes into hiding while his partner seeks to catch him/her. The act is usually accompanied by singing a song. When your partner is able to locate and catch you, you will then be the next to seek your partner.

This form of entertainment using traditional storytelling and dances has influenced our moral upbringing by teaching us good values and a decent way of life. It is also pertinent to note that they have been transposed into the media as forms of interlude and social activities. Demonstrating them in different aspects of the media and also using them in Home video production significantly influence the conduct of this research. 


\section{Corpus of Oral Tradition in African Night's Entertainment}

African Night's Entertainment tells about an old man who narrates a story to some villagers (Abeng, 2017). This section provides the summary of the story.

The story begins with a man called Mallam Shehu who had a dream that he was in a marketplace where he saw a horse he admired and eventually bought it and paid for it. Nevertheless, this horse is said to have been paid for by another man, but Mallam Shehu in a bid to acquire the horse by all means paid an extra amount of money to influence the sale in his favour. Meanwhile, the initial buyer who already bought the horse was upset and confronted Mallam Shehu and said "Mallam, why do you want to deprive me of my bargain?" He replied, "not so my friend. I want the horse, you want the horse. The seller wants money, and to whom should he sell?"This insinuates that the highest bidder buys the commodity (horse).

Eventually, Mallam Shehu claimed the horse and the horse grew beautifully in his house. Subsequently, the horse gave birth to a colt. Mallam Shehu loved the colt as much as the horse. As soon as the colt was ripe to be ridden, he mounted it, rode out into the town, where it limbed into a gallop. The horse stumbled. Mallam Shehu fell, breaking an arm and leg. Immediately, he woke up from this dream, suffocated with sweat. On this, Mallam Shehu consulted a soothsayer who interpreted his dream. The seer told him the horse signified a woman.

Although, Mallam Shehu had three wives but none gave him children. As wealthy as he was, this was his ultimate desire. He recalled what was told to him that "horse (woman) would be the only one to bear him a son but he would suffer a great deal." The seer does not advise him to desire this woman nor child but Mallam Shehu replied, "Will Allah indeed let me see a son of my own? If so, I don't care how much I suffer after that."

In the course of time, Mallam Shehu's servants came to his chamber to tell him about a damsel they noticed within the community, which is Mallam Audu's daughter called Zainobe. She was engaged to a man, Abu Bakir from her infancy. They were deeply in love with each. Zainobe was so beautiful that her mother doubted if a commoner like Abu Bakir was worthy of her and Abu Bakir's mother felt the same way. Zainobe was always in-door and rarely went out, so she was hardly noticed by people. Little wonder that Mallam Shehu had never seen her untill now. He persistently sent his servants to ask her to always stop over to see him. She always replied, "Tell him I am not a man, I cannot come alone to see him. That is not proper."

Mallam Shehu finally requested that he wanted to marry her. She told him she already had a fiancé and only Allah could separate them. Meanwhile, Abu Bakir came to know about Mallam Shehu's request. This made him uncomfortable and said this to her:

Women are like water and horses. Women are like water because you cross a stream in the dry season and when you return in the rains, the same stream will drown you. If you love a horse very much and you feed her, she'll throw you down and break your backbone. So is a woman's love. Dry today like an ebb tide, high tomorrow like a flood." - Abu Bakir 
Zainobe pledged her loyalty to Abu Bakir, and she said, "You speak of deep things Abu. But I'm not that kind of woman. Nothing will ever make me marry Mallam Shehu, unless he's prepared to marry my dead body".

In one of the servant's errands to Zainobe, Abu Bakir stopped the servant and beat him mercilessly. Mallam Shehu in his lust still qwnt back to the seer to request love charm. The seer again forewarned him against it but he ignored his advice. The seer prepared a secret appealing love charm for him and Mallm Shehu sent his trusted servant to get it spread on Zainobe's body. The servant succeeded in doing that.

As the charm began to take effect, Zainobe beame entangled into it, and she always lied to her mother that she was going out to see Abu Bakir and went to see Mallam Shehu instead. Mallam Shehu always requested his servants take her to a special room in his house. After they conversed, he always gave her a perfume as a gift. The scents had charm to change Zainobe's mind to love him. Because of this, she always lied to her mother that she was with Abu Bakir. Meanwhile, after some time of not seeing Zainobe, Abu visited her, just for him to discover Zainobe's pranks. He left her house in anger. Her mother scolded her saying "That's a lie! Abu has been here all the time, waiting for you to return." Zainobe stamped her foot angrily, "So it has come to this, he now follows me around ... I know Abu has been looking for an excuse to quarrel with me."

Her mother eventually, inhaled the perfume (potion) given to her by Mallam Shehu and the charm took effect on her. From that moment, she advised Zainobe not marry Abu Bakir saying that he was not worthy of her. Zainobe went to see Abu Bakir in anger and for the first time she was rude to him. She said,

When a trader gets hold of some good cloth and has taken it to the market, at least 10 bidders will price it before he sells it to the highest bidder. A girl who has never been married is like a cloth in the marketplace." - Zainobe

Abu Bakir was angry that he threatened to flog her. Although, he was able to control his anger, he rather chose to report her to her father. When Zainobe's mother sided her, the father whipped Zainobe and her mother heartlessly. Without her father's consent, Zainobe went ahead to marry Mallam Shehu. Although, the wedding was fantastic and the talk of town, her father refused to be a part of it. Mallam Shehu straightaway spent generously on Zainobe's family, the King and other influential people. Unfortunately, Abu Bakir's bride price which he deposited was returned to him. Mallam Audu, Abu Bakir's father refused the money but his wife collected it back. In anger, Abu Bakir refused to touch the returned bride price and promised to have his vengeance in due time. Afterwards, Abu Bakir embarked on a journey of vengeance. He carried along with him a bow, arrow and a few pence and went on his search for vengeance. He asked his brother to behold their mother.

After some time, say a year later, Zainobe gave birth to a son, named Kyauta. The boy was said to be handsome and good looking and good mannered, and everyone cherished him. Immediately, Mallam Shehu built Kyauta a beautiful house within the palace. Kyauta's playmates visited him and played with him within the compound. As years pass by, Abu Bakir was still on his search for vengeance. 
After passing through ugly and dreaded experiences, he finally was directed to a village called the village of rejects. Coincidentally, he met with the village head called Mallam Tausayinka, who incidentally was also a seer. Going through his crystal ball, he foresaw the mission of Abu Bakir and he advised as thus:

You are thinking of injuring Mallam Shehu for taking Zainobe from you. Your idea is that he has done so because he has more money than you do. That idea is wrong. Mallam Shehu took the girl from you because he has looked for a son for 35 years in vain. One night he dreamed that if he married your betrothed, she will bear him a son. And now the prophecy has been fulfilled... if you set eyes on this child, you will not want to harm one hair on his head. Go and rest, Zainobe still loves you ...let Allah avenge you." Tausayinka

Abu Bakir was not satisfied with the reply and he suggested: "Can't it be arranged that this same son should be the cause of his death?" Tausayinka now commited Abu Bakir to taking an oath that the vengeance of Allah would be on him. Abu Bakir went ahead to take the oath. Tausayinka then requested Abu Bakir to go and get him a sap from a special tree in a forest from a faraway town, to prepare the charm.

In a nutshell, this deadly mission recounts that Abu Bakir experienced starvation, and was attacked by robbers. His ear was cut off; he lost an eye, was jailed, sustained blisters in his feet but nevertheless, he did not give up. He was a hardworking and honest man full of determination to fulfil a task. He worked hard to raise money. Despite all these, everyone advised him to give up his quest for vengeance. Abu Bakir refused; he eventually got the sap through an old witch who helped him. Having gotten the charm, Abu Bakir returned years later. The charm was prepared for him by Tausayinka. He was to apply the charm on Kyauta. Tausayinka gave Abu Bakir a talisman to assist him access Kyauta's room invisibly.

Abu Bakir returned to his home town Galma, he confided in his mother and brother to keep his return secret and threatened to be hostile if they did not. His brother showed him Kyauta, Zainobe's son the following day. That night, he wore the talisman; this gave him access Kyauta's room unnoticed, he then rubbed the charm on Kyauta. After doing that, visited Zainobe and said to her,

"You have disgraced me. You have caused me untold suffering. It is written that you shall pay for all this in this world. Your present husband took you away from me because he wanted a son. That son shall be a curse to you." (Abu Bakir)

As revealed to her in a dream, Zainobe jumped up from sleep, filled with fear. She ran into Kyauta's room to check on him. She found him sleeping peacefully. With this, she resolved that it was just a dream and went back to bed. When Kyauta woke up that morning, he became a changed boy who went into juvenile delinquencies. He started stealing and became a thief, a liar and a rude boy. He disgraced his father and the entire family. Mallam Shehu had to pay for everything 
Kyauta stole. It became embarrassing for both Mallam Shehu and Zainobe. Mallam Shehu tried all corrective measures but nothing seemed to work. More so, Zainobe always intervened. Kyauta's abnormal conditions grew worse on a daily basis. He stole 100 pounds from his father, and then relocated to Kano, stole more, and was imprisoned many times.

When, Kyauta came out of prison, he got a job and remained honest. He served the clerk faithfully and encouraged him to start a business. Kyauta's honesty was tested so many times and he succeeded. The clerk trusted him and opened a shop in another town for him to manage. Unfortunately, he did not remit funds for months. He was arrested and imprisoned. When the case was heard, his father bailed him by paying the clerk the 400 pounds he demanded for damages.

Adding insult to injury, Kyauta gwent into armed robbery. He easily slipped off handcuffs. He escaped from his father's imprisonment and relocated to Lagos, where he met Dogo. Kyauta and Dogo became friends and went on raids as Dogo advised: "if they catch you, go with them. You know when you are fed up with them, that's the time to make your getaway." - Dogo

Abu Bakir's attitudes brought shame to Mallam Shehu. He then relocated and took on a new identity as Mallam Usman with his wife, Zainobe. One day, Kyauta and Dogo saw a beautiful house and then planned to raid the house that night. That same night, they robbed the house. During the robbery, a figure lurked in the shadows and Kyauta shot him in fear. As they bolted, he saw Zainobe at the door and recognised her; he then ran into her arms. Upon inquiry, he learned he had just killed his father, Mallam Shehu who had just relocated to this town and disguised himself as Mallam Usman to hide from the shame he - Kyauta has brought to them. The scales of the charm fell from his eyes. She cried as she told him Mallam Usman was his father. She showed him a secret passage and he escaped.

Unfortunately, Dogo was caught. He snitched on Kyauta but Kyauta was never caught. Zainobe then told the King of the town that Mallam Usman's son would arrive on a certain day. She planned with Kyauta and they agreed on that day. He came as planned and the King gave him a grand welcome. He looked so much like Mallam Usman and at the sight of him, everyone sympathised with him.

Kyauta shared his father's property between the king, the poor and Mallam Shehu's wives. Zainobe remembered her dream about Abu Bakir and told Kyauta. It occurred to her that, it was not just a dream, but a dream come true. Kyauta came back to his senses. After the whole scenario, Kyauta and his mother Zainobe travelled back to Galma. Abu Bakir was old, frail and disfigured. Kyauta visited him and cut off his head from his body with a sharp sword. After which he fled for a year and came back to take care for his mother (Zainobe).

The narrative has demonstrated the nature of Cyprian Ekwensi's narrative style. The story consists of diverse aspects of oral tradition. The demonstration of African folklore is reflected through the use of folktale, myth, legend, proverbs, traditional beliefs or tradition and religion. Ekwensi uses these elements of oral narratives to convey his message, given that traditional ancient stories are part of African culture used as entertainment. The moral and ethical conflicts in the story demonstrate the nature of African settings. The moral implication is that one should learn to forgive when extremely hurt. Zainobe betrays Abu Bakir, Mallam Shehu uses 
diabolic means to influence his relationship with Zainobe (which is wrong). Abu Bakir's quest for vengeance brought about the tragedy in the story. The dramatic twist in the story is that the law of nature is tampered with.

African folklore consists of African culture and tradition which is demonstrated in the story. African tradition is characterised by force marriage, infant courtship, belief in charms, belief in traditional medicine and witchcraft. Revenge or vengeance is one of the attributes of an uncivilised African community. All these constitute the motifs found in Ekwensi's African Nights Entertainment.

\section{Discussion and Conclusion}

Persistence in contemporary interests on African folklore and its derivatives is influenced by the reality that African oral arts or oral tradition still exist in the works of prominent literary writers and new literatures. For decades, it is considered the fashion of African literature where many literary writers drew their inspiration from. Edward (1991) comments that "the conscious exploration of its tropes, perspectives, philosophy and consciousness, its complementary realism, and ontology, for the delineation of authentic African response to memory, history and other possible comparisons with modern existence such as witnessed in recent developments of the African novel."

Oral narratives have been the experimented texts for early writers in a way that popular literature created by literary writers or storytellers of the market place and those of inner-city employ the original materials of the oral tradition. Some writers drew their inspirations from the spring of living oral traditions. The thematic and structural importance of African traditional stories to the development of African literature is demonstrated in the works of prominent African writers like Ngugi wa Thiong'o, Chinua Achebe, Wole Soyinka, Kofi Awoonor, Ama Ata Aidoo and host of them. These writers adopted elements of orality as themes, styles and structure in their narratives. Through African oral tradition such as The African oral tradition - the folktale, the proverbs, the myths, the legends, the songs, the idioms, the incantations and the riddles, African literature is able to promote and defend the African heritage. Myths are treasured in peoples' culture and beliefs. They are seen as stories enrooted in African folklore beliefs or religion. They interpret or attempt to clarify the origins and fundamental values of a given culture and the nature of the universe and humanity. In the modern day Africa, myths are still held in high esteem because they are believed to be stories that are true based on their supernatural influence on events. Edward (1991) in his defence of Chinua Achebe as a forerunner of the literary movement that seeks to protect the African heritage and tradition comments that:

Achebe is undoubtedly sensitive to the African oral tradition, but he appears to be less innovative when it comes to the deployment of oral literary structures. One is therefore not surprised that all Achebe's novels-from Things Fall Apart through Anthills of the Savannah-are structurally in the mode of the great Western tradition. It is useful for one, in attempting to explore influences of the African oral tradition on the novel form, to be 
clear as to what is typically African and what is exclusively African or what is borrowed to nourish the African tradition.

Cyprian Ekwensi and other well-known African writers today find succour in the use of folklore in their early works. In his early works which is a collection Ikolo the Wrestler and Other Ibo Tales, and An African Night's Entertainment, the novel Burning Grass, and the juvenile works The Leopard's Claw and Juju Rock, Ekwensi told stories based on traditional folktales that depict a rural setting. In Burning Grass Ekwensi follows the adventures of Mai Sunsaye, who has Sokugo, wanderlust, and of his family, who try to rescue him. While seeing his protagonists through varied adventures, Ekwensi portrays the lives of the Fulani cattlemen. Ekwensi has used the African traditional folktales to draw the attention of young people into liking literature. This early works, which has been considered one of the author's more "serious" novels, greatly influenced the reading culture of many young readers across Nigeria and Africa.

Although, central themes in contemporary African literature and African literary traditions, followed the parameters introduced by the influence of Christianity and Islam. This afterwards brought about the struggle between rural and urban life, traditions and secular (modern), culture and religion, generations and gender issues. However, the oral tradition has great influence on the early works of the first generation of Nigerian and African writers. Folklore is evident in popular literature drawn from oral storytellers like Cyprian Ekwensi's African Night Entertainment. These stories dwell the realm of African tradition. The early writers weaved and built their fictional storylines along the African traditional stories. Some are a collection of oral tradition fused together; while some writers intelligently adapted or tailored their literary prowess towards translating literary works into African languages. Others incorporated existing oral traditions.

Evidence in modern African literary writing reveals that there is obvious interplay between the existing African oral tradition and literary traditions of the twentieth century. The dominance and placement of orality and other traditional oral forms within the context and style of African writers expressed their efficacy in fictional writing. A volume of literary works have taken from oral features to build in their writing style. Early writers like Amos Tutuola and D.O. Fagunwa in Nigeria, S.E.K. Mohayi in Xhosa, South Africa and Mario Anthonio in Portuguese explore the use of African folklore in their works.

The early African writers comprehend the potentials in oral tradition; its images, structures and resources. Therefore, they took advantage of that to develop their style of writing by giving oral tradition a literary approach. In South Africa, Sinxo Guybon found the relationship between African folklore and his popular Xhosa fictions. The same trend of characterised the writings of O.K. Matsepe in Sotho, A.C. Jordan in Xhosa, Rolfes Robert Reginald Dhlomo in Zulu. These writers explored and established the relationship between oral tradition and literary written materials. Despite the influence of European tradition, these literary artists connected these artistic activities of popular fiction, oral tradition and other serious literary writings. To a large extent, African writers like Chinua Achebe, Wole Soyinka, Oswald Mtshali, Mazisi Kunene, Ayi Kwei Armah, Nardine Gordimer. Mariama Ba, Aminata Forna, 
Ngugi Wa Thiong'o are indebted to the African oral tradition in their ventures of creative writings. For instance, traditional epic and folktales for example have influence the rise of the novel and early writers of the $20^{\text {th }}$ century. Equally, pioneer Nigerian writers like Cyprian Ekwensi's African Nights Entertainment (1962) is a reduplication of a collection of traditional folktales and other forms of oral tradition narrated in literary form. Wole Soyinka's Death and the King's Horseman is a replica of the people's inherited beliefs and culture in a literary approach. Ola Rotimi's The Gods Are Not To Blame is an adaptation of the Greek classic Oedipus Rex (1968) recast in Yoruba traditional setting as a play. Other Nigerian and African writers like Amos Tutuola, D.O. Fagunwa in Yoruba, and Samuel Edward Krune Mghayi in Xhosa have their classic works either retold, recast or transcribe from the oral tradition.

The prospects and future of folklore are found in recent global developments in community radio, television and its rapid spread in rural Africa which made speech recording facilities available within rural Africa. It gives the society a capacity to record their thoughts, ideas and beliefs without being able to read and write. These new approaches to information documentation are consciously cultivated to serve the specific needs of oral cultures. They should also be seen as an opportunity for technology to enhance the way people live without necessarily altering their ways of life. Opportunities are created thus to the global knowledge production industry to tap into the indigenous knowledge of various oral cultures in Africa and other parts of the world. The potentialities of the global information community will be increased since there is a diversity of knowledge and knowledge systems available now.

To sum up, in the context of literary criticism, the suppression of the ethnic factor has taken the form of erasing the ethnic presence in the literary history of individual countries. Gerard (1981) insisted on the inclusion of the ethnicity in literatures of Africa. He claimed that there has always been:

a vague reference to 'orature', a label that neither properly designates the complex literary resources of diverse group-ethnicities nor reflects their nature. However, other critics assume that identifying ethnicity in African literature may be a major step towards developing a viable alternative to literary dominance. (pp. 31-32)

Thus, it is safe to conclude to that contemporary African writers owe much to African oral tradition in their various domains of literary inspirations.

\section{References}

Abeng, B. (2017). African nights entertainment. Retrieved from http://mindadventures.club/an-african-nights-entertainment

Chapin, H. (1992). Nigeria: a country study. Washington, D.C.: Federal Research Division, Library of Congress

Ekwensi, C. (1948). When love whispers. Onitsha, Nigeria: Tabansi Bookshop

Ekwensi, C. (1962). An African nights entertainment: A tale of vengeance. Ibadan, Nigeria: African Universities Press. 
Ekwensi, C. (1964). Literary influences on a Young Nigerian. Times Literary Supplement, 4, 475.

Ekwensi, C. (1996). African nights entertainment (African readers library). London, England: Hodder Murray.

Ekwealor, C. C. (2009). AgumaguEderede Igbo N'ozuzuoke. Enugu, Nigeria: Daschal Communications.

Devantine, F. (2009) Written tradition and orality, oral tradition. The International Journal of Research into Island Cultures, 3(2).

Edward, S. (1991). Oral Tradition and the African novel. MFS Modern Fiction Studies, 37, 389-407.

Emenyonu, E. N. (1978). The rise of the Igbo novel. Ibadan, Nigeria: Oxford University Press.

Finnegan, R. (2017). Oral literature in Africa. Cambridge, England: Open Book Publishers.

Gerard, A. (1981). African language literatures: An introduction to the literary history of sub-Saharan Africa. London: Longman.

Goody, J., \& Watt, I. (1963). The consequences of literacy. Comparative Studies in Society and History, 5(3), 304-345.

Haley, A. (1976). Roots: the story of an American family. New York, NY: Doubleday.

Larson, C. R.(1971). The emergence of African fiction. Bloomington, IN: Indiana University Press.

Okpewho, I. (1979). The epic in Africa. New York: Columbia University.

Okpewho, I. (1990). The oral performer and his audience: A case study of the Ozidi saga in The Oral performance in Africa. Ibadan, Nigeria: Spectrum Books.

Okpewho, I. (1992). African oral literature. Bloomington, IN: Indiana University Press.

Onyekaonwu, G.O. (1986). The development of modern lgbo prose fiction, 19331983: An historical and stylistic survey. Unpublished Ph.D. Thesis, University of Ibadan, Nigeria.

Ukadike, F. N. (1994). Black African cinema. Berkeley: University of California Press.

Ukadike, F. N. (2000). Images of the reel thing: African video-films and the emergence of a new cultural art. Social Identities, 6(3), 237-40.

Westley, D. (1991). A bibliography of African epic. Research in African Literatures, 22(4), 99-115. 